\title{
Excitatory and Inhibitory Circuitry in the Superficial Gray Layer of the Superior Colliculus
}

\author{
Psyche H. Lee, ${ }^{1}$ Matthias Schmidt, ${ }^{1,2}$ and William C. Hall ${ }^{1}$ \\ ${ }^{1}$ Department of Neurobiology, Duke University Medical Center, Durham, North Carolina 27710, and 2Department of \\ Zoology and Neurobiology, Ruhr-University, D-44780 Bochum, Germany
}

\begin{abstract}
Stratum griseum superficiale (SGS) of the superior colliculus receives a dense cholinergic input from the parabigeminal nucleus. In this study, we examined in vitro the modulatory influence of acetylcholine (ACh) on the responses of SGS neurons that project to the visual thalamus in the rat. We used whole-cell patch-clamp recording to measure the responses of these projection neurons to electrical stimulation of their afferents in the stratum opticum (SO) before and during local pressure injections of ACh. These colliculothalamic projection neurons (CTNs) were identified during the in vitro experiments by prelabeling them from the thalamus with the retrograde axonal tracer wheat germ agglutinin-apo-HRP-gold. In a group of cells that included the prelabeled neurons, EPSCs evoked by SO stimulation were significantly reduced by the application of ACh, whereas IPSC amplitudes were significantly enhanced. Similar effects were observed when the nicotinic ACh receptor agonist lobeline was used. Application of the selective GABA $A_{B}$
\end{abstract}

Projection neurons within the superficial gray layer, stratum griseum superficiale (SGS), of the superior colliculus relay visual signals that arrive from the retina and cortex to diverse structures, including visuosensory regions of the thalamus, the deeper, premotor layers of the superior colliculus, and the parabigeminal nucleus of the lateral midbrain tegmentum (Benevento and Fallon, 1975; Robson and Hall, 1976; Harting, 1977; Harting et al., 1978; Sherk, 1979; Torrealba et al., 1981; Holstege and Collewijn, 1982; Reese, 1984; Taylor et al., 1986; Redgrave et al., 1987; Hall and Lee, 1997; Künzle, 1997; Lee et al., 1997). Of the structures that receive projections from SGS, the parabigeminal nucleus $(\mathrm{PBN})$ is of special interest because it also is the source of a dense reciprocal projection of cholinergic axons that terminates within SGS (Graybiel, 1978; Edwards et al., 1979; Watanabe and Kawana, 1979; Roldan et al., 1983; Sefton and Martin, 1984; Taylor et al., 1986; Baizer et al., 1991; Jiang et al., 1996). The prominence of this projection suggests that it plays an important role in the modulation of the visual signals that are relayed by the SGS projection neurons to other brain structures.

Despite the prominence of this cholinergic pathway, few studies have addressed the question of its contributions to collicular

\footnotetext{
Received May 21, 2001; revised July 2, 2001; accepted July 23, 2001.

This study was supported by National Institutes of Health Grant EY08233 and the Deutsche Forschungsgemeinschaft (a "Heisenberg" fellowship to M.S. and Sonderforschungsbereich 509 "Neurovision"). We thank Dr. Michael Platt for his helpful comments on this manuscript.

Correspondence should be addressed to Dr. Matthias Schmidt, Allgemeine Zoologie und Neurobiologie, Ruhr-Universität Bochum, ND 6/25, D-44780 Bochum, Germany. E-mail: mschmidt@neurobiologie.ruhr-uni-bochum.de.

Copyright (C) 2001 Society for Neuroscience $\quad 0270-6474 / 01 / 218145-09 \$ 15.00 / 0$
}

receptor antagonist 3-[[(3,4-dichlorophenyl)-methyl]amino]pro pyl](diethoxymethyl)phosphinic acid blocked ACh-induced reduction in the evoked response. In contrast, the ACh-induced reduction was insensitive to application of the $\mathrm{GABA}_{\mathrm{A}}$ receptor antagonist bicuculline. The $A C h$-induced reduction was also diminished by bath application of muscimol at the low concentrations that selectively activate $\mathrm{GABA}_{\mathrm{C}}$ receptors. Because $\mathrm{GABA}_{C}$ receptors may be specifically expressed by GABAergic SGS interneurons (Schmidt et al., 2001), our results support the hypothesis that ACh reduces CTN activity by nicotinic receptor-mediated excitation of local GABAergic interneurons. These interneurons in turn use $\mathrm{GABA}_{B}$ receptors to inhibit the CTNs.

Key words: acetylcholine; nicotinic ACh receptors; muscarinic ACh receptors; cholinergic circuits; interneurons; patch clamp; superior colliculus function. One important exception is the recent in vivo demonstration by Binns and Salt (2000) that iontophoretic application of the ACh nicotinic receptor agonist lobeline reduces the amplitude of visually evoked responses in the rat superficial gray layer. This reduction in the evoked response could be blocked by coapplication of $\mathrm{GABA}_{\mathrm{B}}$, but not $\mathrm{GABA}_{\mathrm{A}}$, receptor antagonists. Binns and Salt (2000) proposed that ACh selectively excites a class of GABAergic interneurons, which in turn reduce the responsiveness of the projection neurons that transmit the visual signals from SGS to other brain structures.

In the present study, we used in vitro whole-cell patch-clamp techniques to directly test their hypothesis at the cellular level. First, we measured the effects of $\mathrm{ACh}$ on the responsiveness of SGS neurons that were identified as projection neurons by prelabeling them with thalamic injections of the retrogradely transported marker wheat germ agglutinin (WGA)-apo-HRP-gold (WAHG). Pharmacological experiments then were used to identify the receptors responsible for the observed effects. Finally, the effects of ACh on projection neurons were compared with its effects on a class of interneurons that were identified physiologically by their expression of $\mathrm{GABA}_{\mathrm{C}}$ receptors (Schmidt et al., 2001). Our results confirm the hypothesis that ACh has a powerful inhibitory influence on the projection neurons of the SGS. The results also support the hypothesis that $\mathrm{ACh}$ exerts this influence by exciting GABAergic interneurons, which in turn inhibit the projection neurons. The primary source of these cholinergic projections, the PBN, is retinotopically organized and may serve to selectively filter the transmission of signals from restricted regions of the visual field. 


\section{MATERIALS AND METHODS}

Prelabeling. Because the effects of ACh within the SGS varied with cell type, the interpretation of our results depended on classifying the recorded cells. To identify projection cells, colliculothalamic projection neurons (CTNs) in the SGS were retrogradely prelabeled with WAHG (E-Y Laboratories, San Mateo, CA). The WAHG was injected into the region of the dorsal lateral geniculate (dLGN) and lateral posterior thalamic (LP) nuclei several days before the patch-clamp experiments. Both of these thalamic nuclei are known to receive projections from SGS (Reese, 1984; Taylor et al., 1986; Mooney et al., 1988; Hutsler and Chalupa, 1991). Putative interneurons were identified by their lack of retrogradely transported WAHG, their morphology, and, for a particular class of interneurons, their expression of $\mathrm{GABA}_{\mathrm{C}}$ receptors. The latter property was assessed by their responsiveness to low $(0.5 \mathrm{mM})$ concentrations of muscimol (Schmidt et al., 2001).

All surgical procedures were approved by the Duke University Institutional Animal Care and Use Committee. Wistar rats were deeply anesthetized with a mixture of ketamine $(60 \mathrm{mg} / \mathrm{kg})$ and xylazine $(10$ $\mathrm{mg} / \mathrm{kg}$ ). The cortex overlaying the posterior thalamus was aspirated, and a modified Hamilton syringe tip filled with WAHG was visually guided into the caudal thalamus. Single or multiple injections of $0.1-0.2 \mu \mathrm{l}$ of WAHG were delivered into this region to prelabel by retrograde axonal transport a population of the CTNs. Animals recovered from the surgery under intensive care and then were returned to their cages until they were used for the slice recordings.

Slice preparation. After a 3-10 d survival time, collicular slices were obtained from 23- to 35-d-old animals as described previously (Lee and Hall, 1995). Briefly, the animals were deeply anesthetized with an intraperitoneal injection of sodium pentobarbital $(50 \mathrm{mg} / \mathrm{kg})$ and perfused transcardially with ice-cold oxygenated artificial CSF (ACSF) containing (in mM): $123 \mathrm{NaCl}, 2.5 \mathrm{KCl}, 1 \mathrm{NaH}_{2} \mathrm{PO}_{4}, 1.3 \mathrm{MgSO}_{4}, 26.2 \mathrm{NaHCO}_{3}, 11$ glucose, and $2.5 \mathrm{CaCl}_{2}$, to which 2.0 kynurenic acid was added. Coronal slices (300 $\mu \mathrm{m}$ thick) were collected and stored in an interface chamber containing ACSF and kynurenic acid for $1 \mathrm{hr}$ at $37^{\circ} \mathrm{C}$ and then at room temperature until recording.

Patch-clamp recordings. Whole-cell patch-clamp recordings were performed under visual guidance as described previously (Lee et al., 1997). Slices were transferred to a submersion-type recording chamber and continuously superfused with oxygenated ACSF. In WAHG-injected animals, prelabeled cells were selected under visual control for recording. Borosilicate micropipettes of 3-7 $\mathrm{M} \Omega$ impedance were filled with internal solution containing $130 \mathrm{~mm} \mathrm{~K}$-gluconate, $2 \mathrm{~mm}$ Na-gluconate, 20 mM HEPES, $4 \mathrm{~mm} \mathrm{MgCl} \mathrm{m}_{2} * 6 \mathrm{H}_{2} \mathrm{O}, 4 \mathrm{~mm} \mathrm{Na} \mathrm{ATP}_{2} \mathrm{AT} 2.5 \mathrm{H}_{2} \mathrm{O}, 0.4 \mathrm{~mm}$ $\mathrm{NaGTP}$, and $1 \mathrm{~mm}$ EGTA, to which $0.5 \%$ biocytin (Molecular Probes, Eugene, OR) was added. The measured membrane potentials were corrected for the junction potential of $-10 \mathrm{mV}$.

Electrical stimulation was delivered to stratum opticum (SO) with an array of eight stainless steel wire electrodes (NB Labs, Denison, TX) spaced $\sim 200 \mu \mathrm{m}$ apart. Postsynaptic responses were evoked with current pulses of $500 \mu \mathrm{sec}$ duration and 3-100 $\mu \mathrm{A}$ in amplitude. These stimulus pulses were sufficient to evoke maximal subthreshold responses. ACh (1 $\mathrm{mm}$ ), $1 \mathrm{~mm}$ lobeline, or $4 \mathrm{~mm}$ methacholine (acetyl-B-methylcholine chloride; all from Sigma, St. Louis, MO) was injected through a micropipette of 1-5 M $\Omega$ impedance by pressure pulses of 5-20 psi delivered by a pneumatic picopump (PV820; World Precision Instruments, Sarasota, FL). The micropipette was located at distances ranging from 50 to 100 $\mu \mathrm{m}$ from the recorded cells. Single-cell responses were recorded before and for $20 \mathrm{sec}$ after the onset of a continuous application of these agents. The significances of ACh-induced effects were tested by one-way ANOVA.

All GABA receptor-related drugs were bath applied. Recordings were started $10 \mathrm{~min}$ after application. This time interval proved sufficient to achieve stable responses (Schmidt et al., 2001). The drugs applied were muscimol, bicuculline methiodide (Sigma), and 3-[[(3,4-dichlorophenyl)methyl]amino]propyl](diethoxymethyl)phosphinic acid (CGP 52432) (Tocris Cookson, Ballwin, MO).

Postsynaptic responses were amplified by a standard patch-clamp amplifier (PC501A; Warner Instruments, Hamden, CT), digitized at $20 \mathrm{kHz}$ (Digidata 1200; Axon Instruments, Foster City, CA), and displayed, stored, and analyzed using pClamp6 software (Axon Instruments). After recording, slices were fixed in $4 \%$ phosphate-buffered formaldehyde and were processed to visualize the recorded neurons that were labeled by diff usion into the cells of the biocytin in the internal solution (Hall and Lee, 1993; Lee and Hall, 1995). To reveal the biocytin, the sections were incubated in $10 \%$ methanol and $0.03 \% \mathrm{H}_{2} \mathrm{O}_{2}$ in $\mathrm{PBS}$, followed by $1 \%$

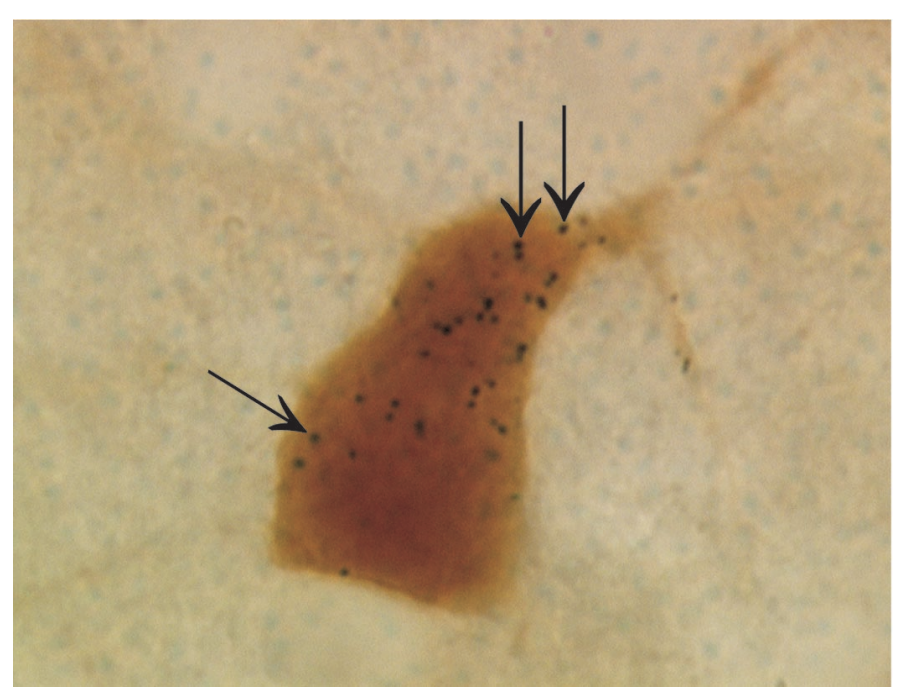

Figure 1. Photomicrograph of a neuron showing dark WAHG spheres (arrows) that were retrogradely transported from injection sites in the thalamus together with the more evenly distributed biocytin, which diffused into the cell from the patch-clamp pipette. This photo was taken after $5 \mathrm{~min}$ of the DAB reaction without heavy metal intensification.

Triton X-100 in PBS, and then they were freeze-thawed in 20\% DMSO. Next, the sections were incubated in avidin with $0.1 \%$ Triton X-100, followed by incubation in biotinylated HRP. Finally, the sections were incubated and then reacted with 3,3-diaminobenzidine. Some sections were processed without intensification to allow simultaneous visualization of both biocytin and WAHG. Alternatively, the sections were reacted with 3,3-diaminobenzidine intensified with cobalt and nickel to allow a detailed morphological characterization of the cells.

\section{RESULTS}

\section{Identification of neurons}

Whole-cell patch-clamp recordings were performed from a total of 56 neurons in SGS under voltage-clamp conditions. In 20 neurons, we could clearly visualize intracellular deposits of WAHG, which was used to retrogradely label CTNs from either the ipsilateral dLGN or LP nucleus. Whereas the WAGH allowed us to identify and select for recording projection cells during the in vitro experiments, filling the cells with biocytin from the patchclamp pipette allowed us to characterize the dendritic morphology of the recorded neurons after the experiments (Fig. 1). We fully recovered the dendritic morphology of eight of the retrogradely labeled cells, and all of these were identified as narrowfield vertical cells (Fig. $2 A-D$ ). We identified putative interneurons based on their dendritic morphology, their lack of retrograde label, and their expression of $\mathrm{GABA}_{\mathrm{C}}$ receptors, as indicated by the reduction of EPSC amplitudes induced by low concentrations of muscimol (Schmidt et al., 2001).

\section{Influence of ACh on SGS neurons}

Whereas electrical stimulation in SO may activate multiple inputs to the superficial layer with diverse effects, the integrated response typically evoked in CTNs at standard holding potential $(-65 \mathrm{mV})$ is an EPSC. The EPSC was occasionally followed by a recognizable IPSC. However, because the EPSCs and IPSCs often overlapped in time, a distinctive IPSC was not always visible.

To study the influence of acetylcholine on evoked postsynaptic responses, we compared PSCs before and $20 \mathrm{sec}$ after the onset of the pressure injection of ACh close to the recorded neuron (Fig. 3). Application of ACh reduced EPSC amplitudes in $87 \%$ of the 


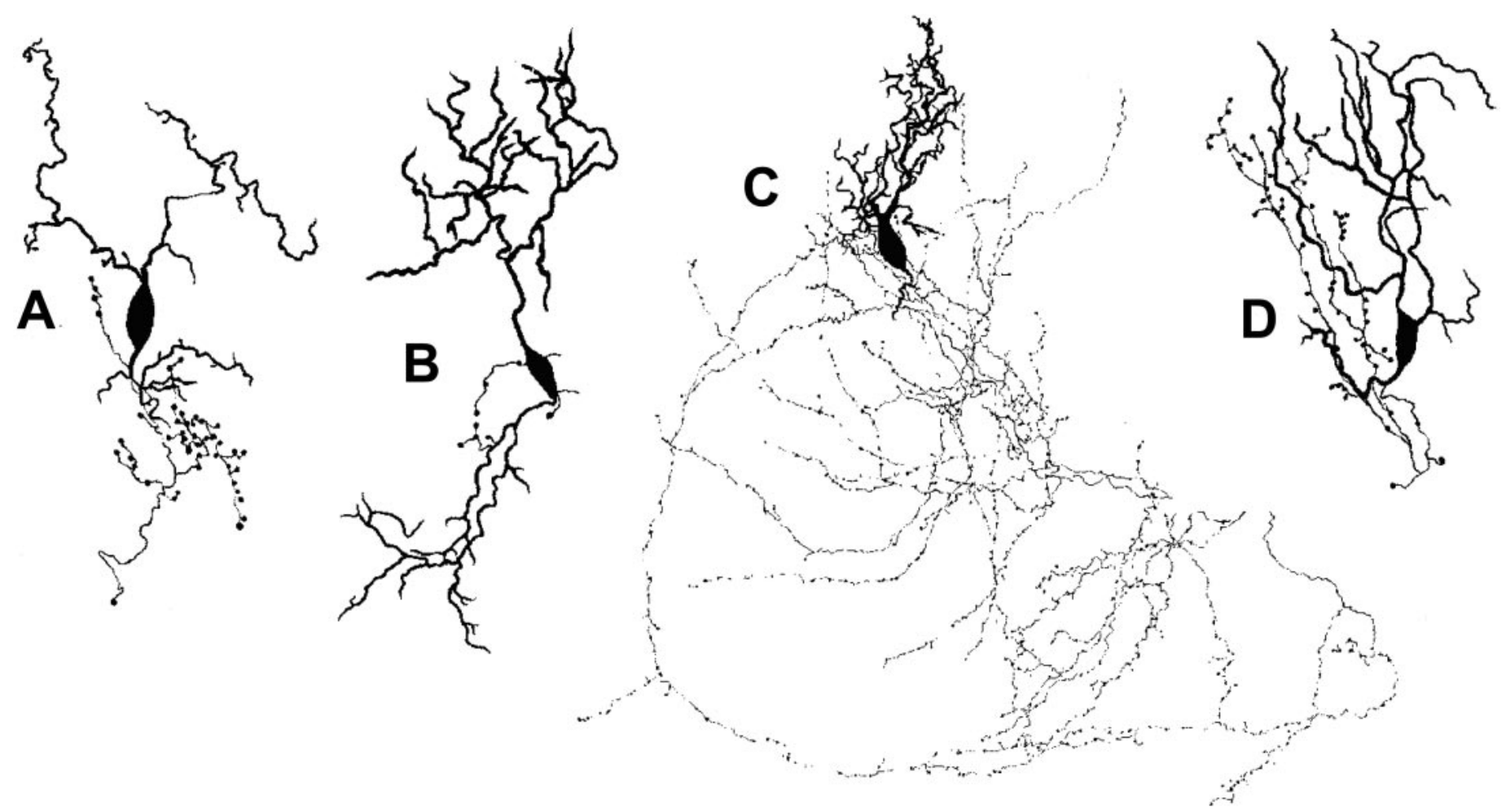

Figure 2. Drawings of four retrogradely labeled colliculothalamic neurons that were filled with biocytin. The double-labeled cells can be identified as narrow-field vertical neurons that were located in upper SGS.

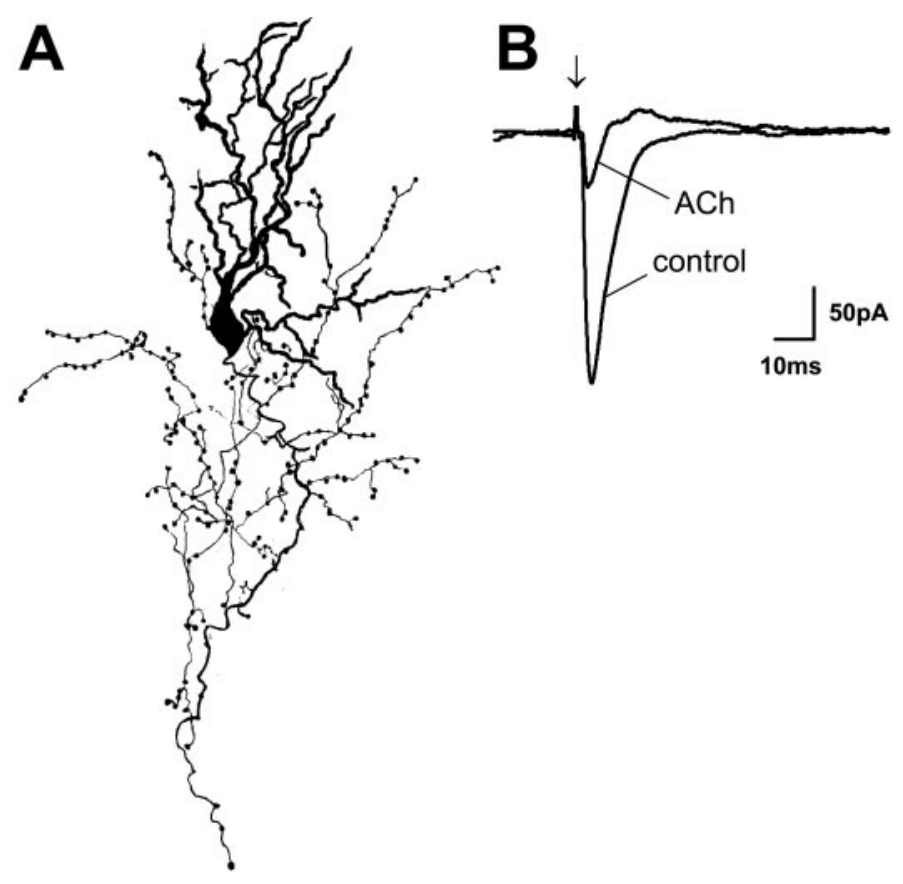

Figure 3. Drawing and recording of a CTN. $A$, The recorded CTN has the morphology of a narrow-field vertical cell. $B$, This record shows postsynaptic currents before (control) and at the end of a $20 \mathrm{sec}$ application of ACh. The application of ACh reduced the amplitude of EPSCs evoked by stimulation of the optic layer (SO). The holding potential for this experiment was $-65 \mathrm{mV}$. The arrow indicates the SO stimulus onset. tested SGS neurons (33 of 38). In particular, all identified colliculothalamic neurons showed significant decreases in EPSC amplitudes, which ranged from 11.2 to $79.1 \%$ (mean of $44.2 \pm$ $23.2 \% ; p<0.01$ ) of the control level.

To characterize the ionic mechanism underlying the AChinduced reductions in EPSC amplitude, we examined the effect of ACh application on neurons clamped at different holding potentials. Figure 4 shows a representative example of such an experiment. At the standard holding potential of $-65 \mathrm{mV}$, ACh application reduced the EPSC amplitude of this cell by $27 \%$ (Fig. $4 A$ ). When the holding potential of the cell was lowered to $-100 \mathrm{mV}$, which was below the reversal potential of $\mathrm{Cl}^{-}(-71 \mathrm{mV})$ and close to the reversal potential for potassium $(-99 \mathrm{mV})$ in our recording conditions, the evoked EPSC showed only a small change after ACh application (-7\%) (Fig. 4B). However, when the cell was clamped at $-110 \mathrm{mV}$, which was below the reversal potential for potassium, the evoked EPSC after ACh application was increased by $15 \%$ (Fig. 4C). This reversal of the ACh effect below the calculated reversal potential for potassium indicated that a potassium current might be responsible for the AChinduced reduction in EPSCs amplitude at the standard holding potential $(-65 \mathrm{mV})$.

Because this result implies an increased inhibitory input to CTNs during ACh application, we expected ACh-induced increases of IPSC amplitudes when recording from CTNs clamped at more positive holding potentials. A representative example is shown in Figure 5. At normal holding potential $(-65 \mathrm{mV})$, ACh application induced a $20 \%$ reduction of the EPSC amplitude without a detectable effect on the IPSC amplitude (Fig. 5A). At a more positive holding potential $(-40 \mathrm{mV})$, ACh application, in addition to reducing the EPSC amplitude ( $-49 \%)$, strongly increased the IPSC amplitude $(+60 \%)$ (Fig. $5 B)$. Similar IPSC 
Figure 4. Effect of the holding potential on ACh-induced PSC changes. Each set of traces shows PSCs before (control), at the end of a $20 \mathrm{sec}$ application of ACh $(A C h)$, and 2 min after $\mathrm{ACh}$ application (recovery). $A$, When the holding potential equaled $-65 \mathrm{mV}$, ACh reduced evoked EPSC amplitude. $B$, At a holding potential of $-100 \mathrm{mV}$, which was close to the reversal potential for potassium, ACh did not change EPSC amplitude. $C$, At $110 \mathrm{mV}$, which was below the reversal potential for potassium, the application of ACh increased EPSC amplitude. Arrows indicate SO stimulus onset.
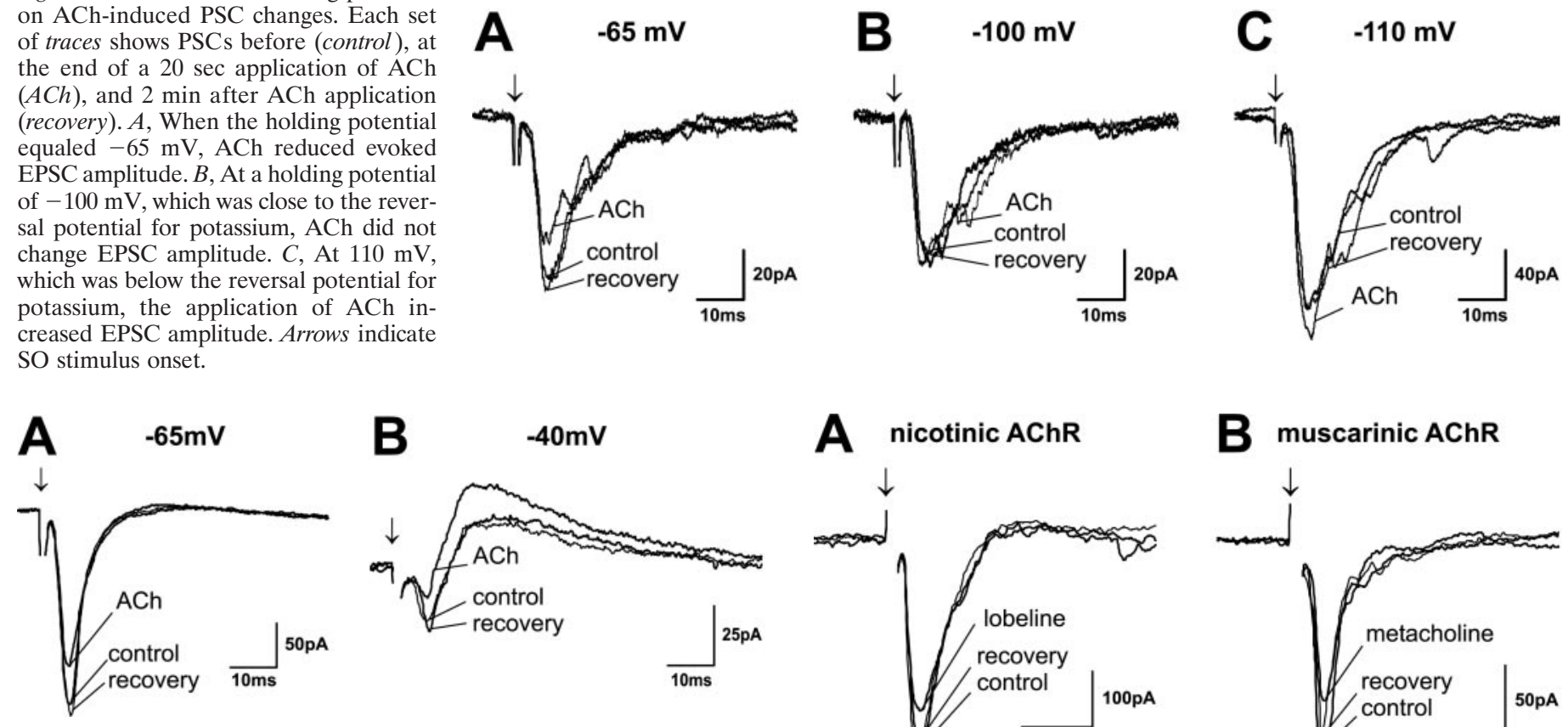

Figure 5. The inhibitory effect of ACh on IPSC amplitude. Each set of traces shows PSCs before (control), at the end of a $20 \mathrm{sec}$ application of $\mathrm{ACh}(A C h)$, and 2 min after ACh application (recovery). A, At a holding potential of $-65 \mathrm{mV}$, ACh reduced the EPSC amplitude. $B$, At a more positive holding potential of $-40 \mathrm{mV}$, ACh application not only reduced the EPSC amplitude but also increased the IPSC amplitude. Arrows indicate SO stimulus onset.

amplitude increases (mean of $37.3 \pm 21.5 \%$; $p<0.01$ ) induced by ACh application were observed in $80 \%$ (four of five) of cells tested.

\section{Pharmacology of ACh effects}

Visually evoked responses of SGS neurons recorded in vivo are dramatically reduced by iontophoretic application of nicotinic receptor agonists but are only slightly reduced in the presence of muscarinic ACh receptor agonists (Binns and Salt, 2000). Therefore, we tested whether our in vitro ACh-induced reductions could be mimicked by application of either the nicotinic ACh receptor agonist lobeline or the muscarinic $\mathrm{ACh}$ receptor agonist methacholine.

The effect of the nicotinic receptor agonist lobeline on postsynaptic responses was tested in six SGS neurons (Fig. 6A). In all cases, lobeline application resulted in a decrease of EPSC amplitudes similar to that observed after ACh applications (mean of $26 \%$ ).

The effect of the muscarinic receptor agonist methacholine on the EPSCs was tested in seven SGS neurons (Fig. 6B). Two narrow-field vertical cells, a horizontal cell, and an unidentified cell showed reduced EPSC amplitudes up to $31 \%$ (mean of 14\%).

\section{Influence of GABAergic inhibition}

In vivo, the ACh-induced reductions of visual responses can be blocked by coapplication of antagonists to $\mathrm{GABA}_{\mathrm{B}}$ receptors but not by coapplication of antagonists to $\mathrm{GABA}_{\mathrm{A}}$ receptors (Binns and Salt, 2000). We therefore examined ACh-induced effects during pharmacological blockage of both $\mathrm{GABA}_{\mathrm{A}}$ and $\mathrm{GABA}_{\mathrm{B}}$ receptors.

To study the consequence of blocking synaptic transmission through $\mathrm{GABA}_{\mathrm{B}}$ receptors, we compared $\mathrm{ACh}$-induced effects

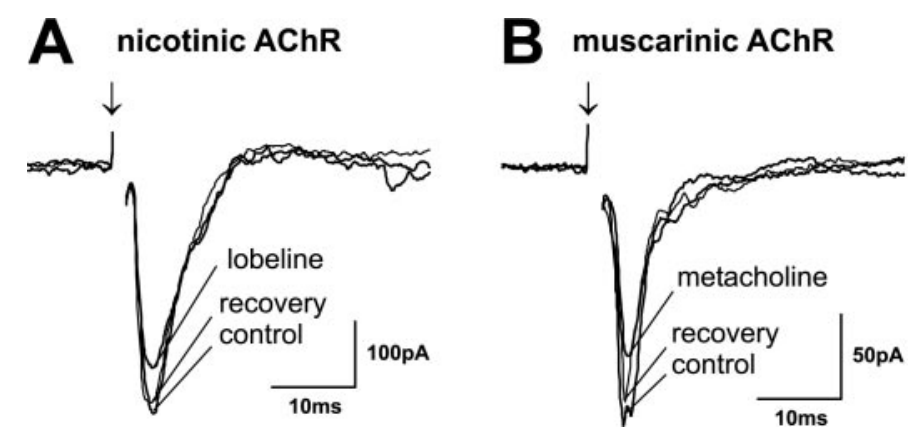

Figure 6. The contributions of nicotinic and muscarinic receptors to the ACh-induced reductions in EPSC amplitude. Each set of traces shows PSCs before (control), at the end of a $20 \mathrm{sec}$ application of ACh $(A C h)$, and 2 min after ACh application (recovery). Applications of both the nicotinic $\mathrm{ACh}$ receptor agonist lobeline $(A)$ and the muscarinic $\mathrm{ACh}$ receptor agonist methacholine $(B)$ reduced the amplitude of the evoked EPSCs. Arrows indicate SO stimulus onset. $A C h R$, ACh receptor.
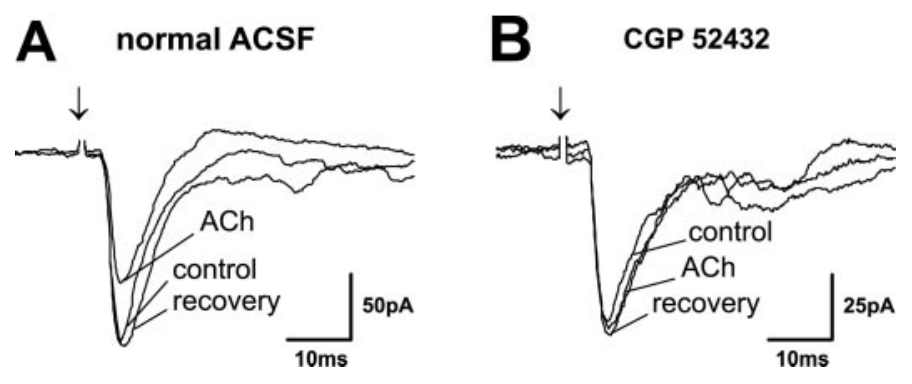

Figure 7. The contribution of $\mathrm{GABA}_{\mathrm{B}}$ receptors to the ACh-induced reductions in EPSC amplitude. Each set of traces shows PSCs before (control), at the end of a $20 \mathrm{sec}$ application of $\mathrm{ACh}(A C h)$, and 2 min after ACh application (recovery). $A$, In normal ACSF, ACh reduced the amplitude of the evoked EPSC in this WAHG-labeled narrow-field cell. $B$, In the presence of the $\mathrm{GABA}_{\mathrm{B}}$ receptor antagonist CGP 52432, the AChinduced reduction was blocked. Arrows indicate $\mathrm{SO}$ stimulus onset.

before and during bath application of the selective $\mathrm{GABA}_{\mathrm{B}}$ receptor antagonist CGP $52432(10 \mu \mathrm{M})$. A representative example of such an experiment is shown in Figure 7. In normal ACSF, when no CGP 52432 was present, ACh application reduced EPSC evoked in this cell by $32 \%$ (Fig. $7 A$ ). In the presence of CGP 52432, the same ACh application did not decrease the EPSC amplitude; instead a small increase $(+4 \%)$ was observed (Fig. $7 B$ ). A comparable complete blockage of the ACh-induced EPSC amplitude decreases was observed in $77 \%$ of the cells tested (10 of 13). In the remaining cells, ACh still induced EPSC amplitude decreases during coapplication of CGP 52432, but these decreases were significantly reduced compared with those in normal ACSF. 
A normal ACSF
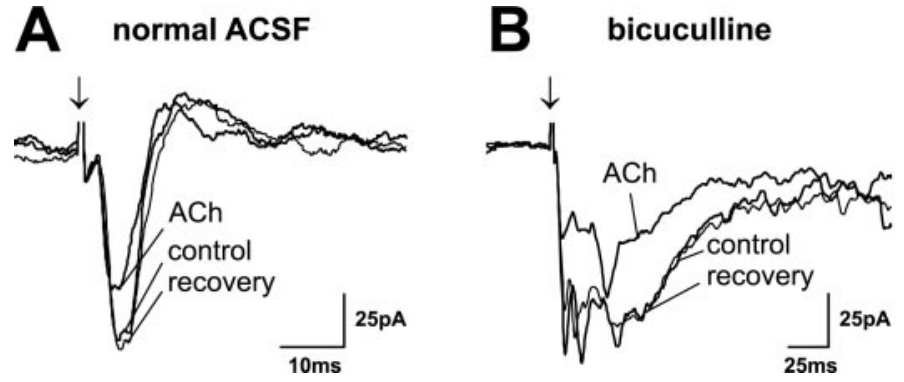

Figure 8. The contribution of $\mathrm{GABA}_{\mathrm{A}}$ receptors to the ACh-induced reductions in EPSC amplitude. Each set of traces shows PSCs before (control), at the end of a $20 \mathrm{sec}$ application of ACh $(A C h)$, and 2 min after ACh application (recovery). A, In normal ACSF (control), ACh reduced the evoked EPSC in this identified colliculothalamic projection neuron. $B$, This reduction was not blocked by the presence of the $\mathrm{GABA}_{\mathrm{A}}$ receptor antagonist bicuculline, although bicuculline greatly prolonged the EPSCs, indicating that it blocked inhibitory inputs that curtail the evoked response of the cell. Arrows indicate SO stimulus onset.

In another set of experiments, we tested whether a blockage of GABAergic transmission mediated by $\mathrm{GABA}_{\mathrm{A}}$ receptors would also affect ACh-induced EPSC amplitude reductions. In these experiments, we compared the ACh-induced effects before and during bath application of the $\mathrm{GABA}_{\mathrm{A}}$ receptor antagonist bicuculline $(20 \mu \mathrm{M})$. Figure 8 illustrates the results from such an experiment. For this cell, ACh application reduced EPSC amplitude by $24 \%$ in the control situation, that is, when no bicuculline was present in the bath solution (Fig. $8 A$ ). In the presence of bicuculline (Fig. $8 B$ ), the EPSC duration in both ACh and control was strongly increased compared with the control situation. This indicates that a blockage of $\mathrm{GABA}_{\mathrm{A}}$ receptor-mediated synaptic transmission removed a significant inhibitory input to this neuron, which normally curtails the duration of evoked postsynaptic excitation. However, application of ACh in the presence of bicuculline still reduced the EPSC amplitude by $29 \%$.

The influence of bicuculline on ACh-induced effects was tested in nine SGS neurons in which ACh application alone significantly decreased EPSC amplitudes. In $89 \%$ of these neurons (eight of nine), coapplication of bicuculline did not block or decrease the ACh-induced reductions in the EPSC. When the effects of both CGP 52432 and bicuculline on the ACh-induced reduction of EPSC amplitude were tested in six neurons, in $83 \%$ (five of six), the ACh effects were completely blocked by CGP 52432 but remained unchanged in the presence of bicuculline.

In a final set of experiments, we tested whether a selective inactivation of GABAergic interneurons in SGS would diminish the ACh-induced reductions of EPCS amplitudes. Because local GABAergic interneurons, but not projection neurons, express $\mathrm{GABA}_{\mathrm{C}}$ receptors in SGS (Schmidt et al., 2001), GABA $\mathrm{C}_{\mathrm{C}}$ receptor activation can be used to selectively inactivate GABAergic interneurons. As has been demonstrated in previous studies, bath application of muscimol at a low concentration in the range of 0.5 $\mu \mathrm{M}$ activates $\mathrm{GABA}_{\mathrm{C}}$ receptors without affecting $\mathrm{GABA}_{\mathrm{A}}$ receptors (Schmidt et al., 2001). The effect of selectively inactivating interneurons using this method on the responses of a CTN neuron is shown in Figure 9. ACh application near this neuron, which exhibited the morphology of a narrow-field vertical cell, reduced its EPSC amplitude by $28 \%$ (Fig. $9 A$ ). In contrast, in the presence of $0.5 \mu \mathrm{M}$ muscimol, which itself did not affect the EPSC amplitude, the reduction of the EPSC amplitude induced by ACh application was only $3 \%$ (Fig. 9B). This suppression of the ACh-
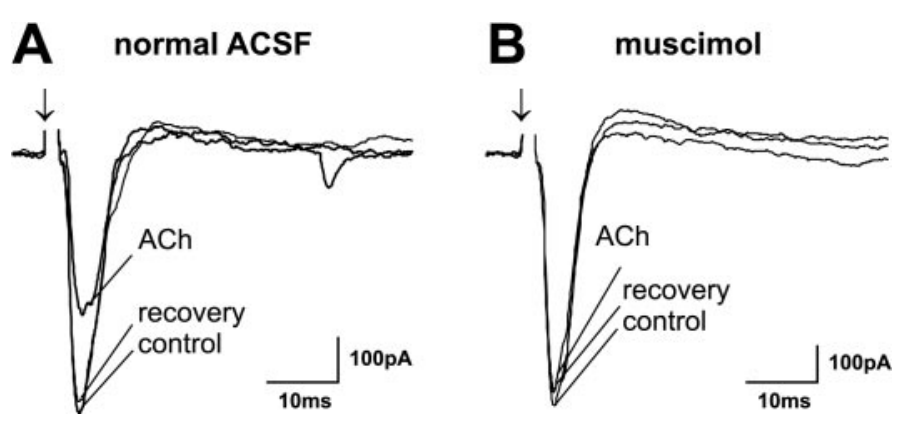

Figure 9. The contribution of $\mathrm{GABA}_{\mathrm{C}}$ receptors to the ACh-induced reductions in EPSC amplitude. Each set of traces shows PSCs before (control), at the end of a $20 \mathrm{sec}$ application of ACh $(A C h)$, and 2 min after ACh application (recovery). $A$, In normal ACSF, ACh reduced the amplitude of the evoked EPSC in this identified colliculothalamic narrowfield cell. $B$, In the presence of muscimol at a concentration of $0.5 \mu \mathrm{M}$ (which selectively activates $\mathrm{GABA}_{\mathrm{C}}$ receptors), the ACh-induced EPSC reduction was greatly diminished. Arrows indicate SO stimulus onset.

\section{summary of ACh effects on CTNs}

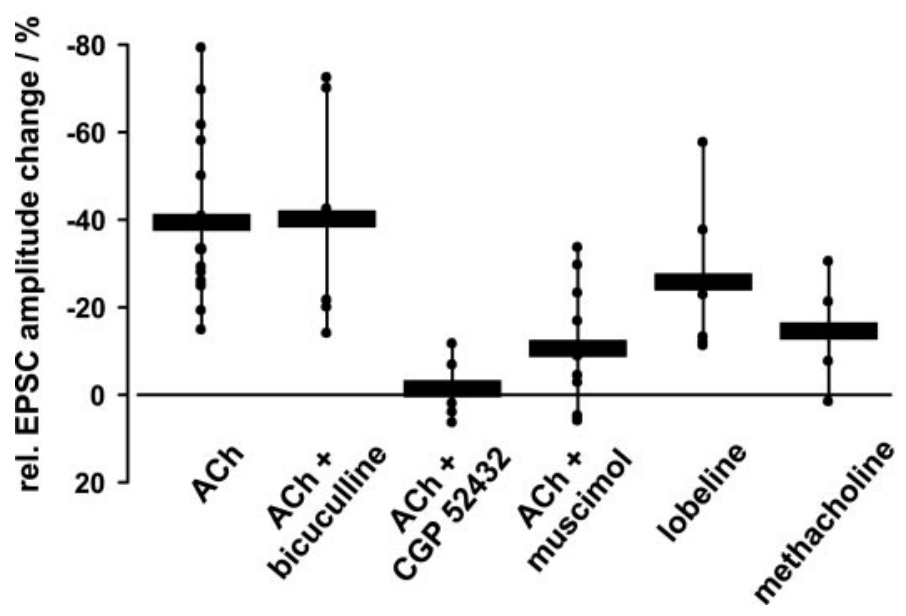

Figure 10. The effect of ACh on CTNs. This chart shows the mean EPSC amplitude reductions (black horizontal bars), as well as the reductions for individual cells ( filled circles) induced by application of ACh, lobeline, and methacholine. The effects on the ACh-induced reductions produced by the $\mathrm{GABA}_{\mathrm{A}}$ receptor antagonist bicuculline, by the $\mathrm{GABA}_{\mathrm{B}}$ receptor antagonist CGP 52432, and by muscimol at a concentration that selectively activates $\mathrm{GABA}_{\mathrm{C}}$ receptors are also summarized.

induced reduction in the EPSC may be attributable to a selective inactivation of GABAergic interneurons presynaptic to the recorded neuron. Overall, bath-applied muscimol, at a concentration of $0.5 \mu \mathrm{M}$, significantly reduced or completely abolished ACh-induced EPSC amplitude decreases in $71 \%$ of the cells tested (10 of 14).

A summary of the results on CTNs is shown in Figure 10. ACh application reduced EPSC amplitudes by $39.3 \%$, lobeline reduced the amplitudes by $25.8 \%$, and methacholine reduced them by 14.4\%. Coapplication of CGP 52432 completely blocked the ACh-induced effects (mean EPSC amplitude reduction of $1.2 \%$ ), and low concentrations of muscimol strongly reduced AChinduced the effects $(10.4 \%)$. In contrast, coapplication of bicuculline did not change the ACh-induced effects (40.2\%).

\section{Interneurons}

Our classification of cells as putative GABAergic interneurons was based on their dendritic morphology, on the absence of any 


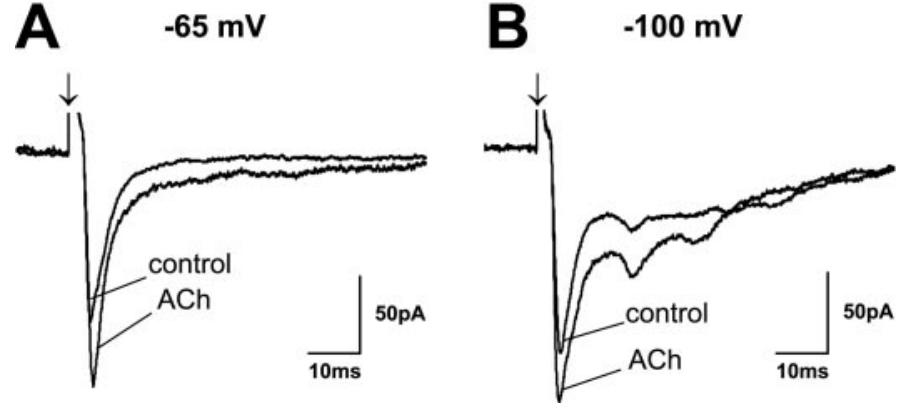

Figure 11. The effect of ACh on putative interneurons. Each pair of traces shows PSCs before (control) and at the end of a $20 \mathrm{sec}$ application of ACh $(A C h) . A$, In contrast to all recorded CTNs, the application of ACh enhanced the evoked EPSCs in this cell when the holding potential was $-65 \mathrm{mV}$. B, ACh-induced EPSC amplitude increases remained relatively unaltered in this cell at a holding potential close to the potassium reversal potential $(-100 \mathrm{mV})$. Arrows indicate SO stimulus onset.

retrograde label after the thalamic injections, and on the strong inhibitory effect on their evoked responses observed in the presence of $0.5 \mu \mathrm{M}$ muscimol in the bath (Schmidt et al., 2001). Our sample of interneurons included one horizontal cell, four piriform cells, and four stellate cells. Whereas the horizontal cell and three of the piriform cells showed decreased EPSC amplitudes during $\mathrm{ACh}$ application similar to those observed for projection cells, ACh had the opposite effect on the remaining interneurons. Results from such a neuron are shown in Figure 11. In this cell, ACh increased the EPSC amplitude by $15 \%$ when the cell was clamped at the standard holding potential of $-65 \mathrm{mV}$ (Fig. 11A). Lowering the holding potential to $-100 \mathrm{mV}$, which was nearly at the reversal potential for potassium, did not change the enhancing effect of ACh on the EPSC amplitude (Fig. 11B). These results were in clear contrast to those obtained in all of the identified projection neurons, in which ACh-induced reductions of the EPSC amplitudes disappeared at this holding potential (Fig. 4).

Three morphologically identified interneurons, one horizontal and two piriform-stellate cells, were tested for the effect of the muscarinic receptor agonist methacholine on EPSC amplitudes. Although EPSC amplitudes increased with methacholine application in both piriform-stellate cells, they remained relatively unchanged for the horizontal cell (Fig. 12A). Similar to the results observed with $\mathrm{ACh}$, lowering the holding potential to $-110 \mathrm{mV}$, which was below the reversal potential for potassium, did not change the amplification effect of methacholine on the EPSCs generated by the piriform-stellate cells (Fig. 12B,C).

\section{DISCUSSION}

We investigated in vitro the influence of $\mathrm{ACh}$ on postsynaptic responses in rat SGS neurons. In colliculothalamic projection neurons, local pressure injections of $\mathrm{ACh}$, the nicotinic $\mathrm{ACh}$ receptor agonist lobeline, or the muscarinic $\mathrm{ACh}$ receptor agonist methacholine reduced the amplitudes of EPSCs that were evoked by electrical stimulation of the subjacent layer, SO. We propose that this ACh-induced reduction is mediated through local GABAergic interneurons for the following reasons. First, the ACh-induced EPSC decreases could be blocked by bath application of the $\mathrm{GABA}_{\mathrm{B}}$ receptor antagonist CGP 52432. Second, bath application of muscimol at a low concentration that has been demonstrated to activate $\mathrm{GABA}_{\mathrm{C}}$, but not $\mathrm{GABA}_{\mathrm{A}}$, receptors (Schmidt et al., 2001) diminished the ACh-induced EPSC decreases. Because activation of $\mathrm{GABA}_{\mathrm{C}}$ receptors is expected to selectively inactivate GABAergic interneurons in SGS (Schmidt et al., 2001), this result suggests that the ACh-induced reductions are mediated by these interneurons. Third, at least a subpopulation of putative GABAergic interneurons, as identified by both anatomical and physiological properties, showed increased EPSC amplitudes in the presence of ACh. Together, these results support the hypothesis that $\mathrm{ACh}$ selectively excites a population of GABAergic interneurons, which, in turn, exerts a $\mathrm{GABA}_{\mathrm{B}^{-}}$ mediated inhibitory influence on projection neurons in SGS. The circuitry that we propose is responsible for these effects is diagramed in Figure 13.

\section{Prelabeling with WGA-apo-HRP-gold}

Fluorescent tracers have been used routinely to retrogradely label cells in living slices (Katz et al., 1984; Edwards et al., 1989). However, fluorescent tracers have disadvantages. First, epifluorescence illumination in the living slice may induce phototoxicity or free radical-induced membrane damage and thus increase the difficulty of obtaining stable recordings (Mendez and Penner, 1998). Although the phototoxic effects can be minimized by rapidly switching from fluorescence to bright-field optics, this procedure is cumbersome and time consuming. Second, fluorescence labels often bleach or fade, especially after histological processing. As an alternative to fluorescent tracers, we used WAHG as a retrograde tracer to prelabel the cells (Menetrey, 1985; Basbaum and Menetrey, 1987; Winer et al., 1996). WAGH is visible in living slices and thus can be used to guide the recording pipette toward the labeled cells. WAGH also has the advantages that the gold label is easily visible under standard bright-field illumination, provides a permanent label that is still visible after the histological processing for biocytin, and, most important, is inert and so causes no damage to the recorded cell. Finally, WAGH spreads only short distances from the injection site and therefore can be precisely deposited in particular structures. For all of these reasons, we regard this tracing method as a versatile tool for in vitro studies in which it is important to classify neurons by their efferent connections.

\section{Effects of ACh on evoked postsynaptic currents}

The effects of ACh on EPSC amplitudes depended on cell type. That is, whereas ACh increased EPSC amplitudes in a population of putative GABAergic interneurons, in all identified projection neurons, it decreased EPSC amplitudes. Similar effects have been reported recently in an in vivo study that examined the influence of cholinergic transmission on visual responses of rat SGS neurons (Binns and Salt, 2000). In the in vivo experiments, iontophoretical application of the nicotinic receptor agonist lobeline and the muscarinic agonist methacholine decreased visual responses. Because this reduction in visual responsiveness could be blocked by coapplication of $\mathrm{GABA}_{\mathrm{B}}$, but not $\mathrm{GABA}_{\mathrm{A}}$, receptor antagonists, it was proposed that $\mathrm{ACh}$ activates local GABAergic interneurons in SGS and that the increased activity of these GABAergic interneurons decreases the activity of SGS projection neurons (Binns and Salt, 2000). By prelabeling cells with WAHG that was conveyed by retrograde axonal transport from the thalamus, we were able to directly demonstrate that the application of $\mathrm{ACh}$, or its agonists, reduces the responsiveness of colliculothalamic cells to input from the optic layer. Furthermore, our ability to block the ACh-induced reductions by either application of the $\mathrm{GABA}_{\mathrm{B}}$ receptor antagonist CGP 52432 or selectively inhibiting GABAergic interneurons with low concentrations of muscimol confirmed that the response reductions in the projection neurons 

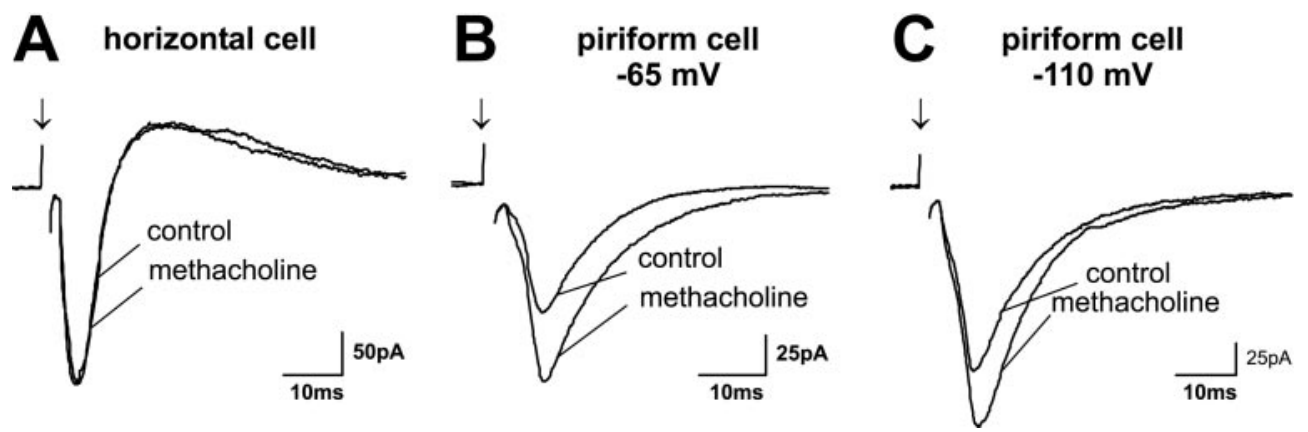

Figure 12. The contribution of muscarinic $\mathrm{ACh}$ receptors to the responses of putative interneurons. Each pair of traces shows PSCs before (control) and at the end of a $20 \mathrm{sec}$ application of $\mathrm{ACh}(A C h) . A$, In contrast to its action on projection neurons, the muscarinic $\mathrm{ACh}$ receptor agonist methacholine did not change EPSC amplitude in an identified horizontal cell. $B$, In another putative interneuron, morphologically identified as a piriform cell, methacholine increased EPSC amplitude not only when the normal holding

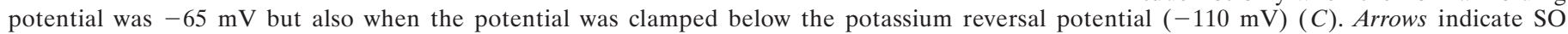
stimulus onset.

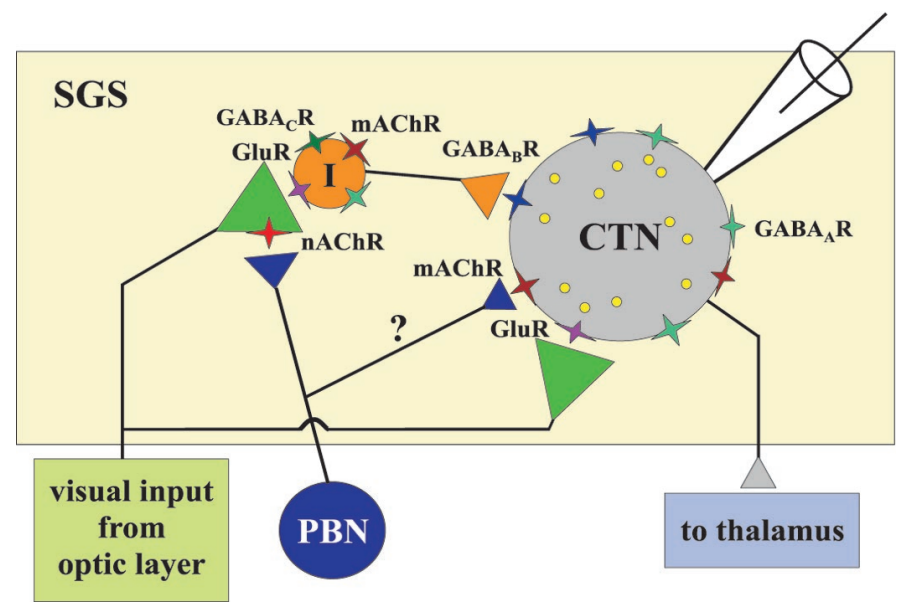

Figure 13. Circuit model to explain the observed effects of ACh on the colliculothalamic neurons in SGS. According to the model, ACh both presynaptically (nicotinic receptors) and postsynaptically (muscarinic receptor) excites a class of GABAergic interneurons. These interneurons, in turn, use $\mathrm{GABA}_{\mathrm{B}}$ receptors to inhibit the CTNs. In the figure, the gold circles in the CTN soma represent WAHG that was retrogradely transported to the cell from an injection site in the thalamus. $G A B A_{A} R$, $\mathrm{GABA}_{\mathrm{A}}$ receptor; $G A B A_{B} R, \mathrm{GABA}_{\mathrm{B}}$ receptor; $G A B A_{C} R, \mathrm{GABA}_{\mathrm{C}}$ receptor; $n A C h R$, nicotinic $\mathrm{ACh}$ receptor; $m A C h R$, muscarinic $\mathrm{ACh}$ receptor; GluR, glutamate receptor.

are mediated indirectly by GABAergic interneurons in SGS. Finally, by recording from interneurons, we were able to confirm that, in contrast to all of the projection cells, a population of interneurons shows enhanced, rather than reduced, EPSCs in the presence of ACh.

Although the results support the hypothesis that the AChinduced EPSC decreases observed in SGS projection neurons are mediated by GABAergic interneurons, several observations indicate that only a subset of GABAergic SGS interneurons is involved. First, the strong disinhibitory influence of bicuculline indicates that a significant amount of the GABAergic inhibition on projection neurons is mediated by $\mathrm{GABA}_{\mathrm{A}}$ receptors (Fig. $8 B)$. Second, evidence suggests that inhibitory mechanisms mediated through $\mathrm{GABA}_{\mathrm{A}}$ and $\mathrm{GABA}_{\mathrm{B}}$ receptors have different functional roles, including surround inhibition and response habituation, respectively (Binns and Salt, 1997). Finally, in our sample of cells, a number of putative GABAergic interneurons did not show EPSC increases when ACh or methacholine was applied. In particular, the one morphologically identified horizontal cell exhibited reduced rather than increased EPSCs in the presence of ACh. Whereas horizontal cells are thought to mediate their inhibitory influence on SGS projection neurons through
$\mathrm{GABA}_{\mathrm{A}}$ receptors, the stellate and/or piriform cells may be presynaptic to $\mathrm{GABA}_{\mathrm{B}}$ receptors (Mize, 1992; Binns, 1999) and mediate the ACh-induced decrease in the responsiveness of the SGS projection neurons.

\section{Nicotinic versus muscarinic $\mathrm{ACh}$ receptors}

Both nicotinic and muscarinic $\mathrm{ACh}$ receptor agonists reduce visual activity of rat SGS neurons in vivo (Binns and Salt, 2000), and both receptor types are expressed at high levels in SGS (Clarke et al., 1985; Zubieta and Frey, 1993; Perry and Kellar, 1995; Whiteaker et al., 2000). These results are consistent with our observation that both lobeline and methacholine can mimic ACh-induced EPSC decreases in narrow-field vertical cells. The methacholine-induced EPSC increases in the two tested piriform cells suggest that GABAergic interneurons may be selectively excited through muscarinic ACh receptors. This activation would in turn decrease responses in projection neurons that are postsynaptic to these interneurons.

Evidence suggests that the nicotinic ACh receptors are located presynaptically on retinal terminals (Prusky and Cynader, 1988). From our results, as well as from the results obtained in vivo (Binns and Salt, 2000), it seems reasonable to further propose that nicotinic receptors are specifically expressed in retinal terminals that provide input to the GABAergic interneurons that are connected to projection neurons through $\mathrm{GABA}_{\mathrm{B}}$ receptors. From the effects obtained with methacholine, it may be proposed that inhibitory muscarinic ACh receptors are expressed by projection neurons and GABAergic horizontal cells, whereas excitatory muscarinic $\mathrm{ACh}$ receptors are specifically expressed by GABAergic interneurons with piriform-stellate morphology. However, although both functional types of muscarinic ACh receptors are present in SGS (Aubert et al., 1992; Zubieta et al., 1993; Levey et al., 1994), nothing definite is known about their cellular localization.

\section{Functional role of the cholinergic input to SGS}

Both in vivo (Binns and Salt, 2000) and in vitro (present study) experiments have demonstrated that ACh exerts a powerful influence on the excitability of SGS neurons. These physiological results are consistent with those from immunocytochemical studies that demonstrate a dense cholinergic neuropil in this layer (Hall et al., 1989; Henderson, 1989; Tan and Harvey, 1989; McHaffie et al., 1991; Jeon et al., 1993). Most of the axons that form this neuropil arise from the parabigeminal nucleus in the lateral midbrain tegmentum (Mufson et al., 1986; Hall et al., 1989; Tan and Harvey, 1989; McHaffie et al., 1991). This small, but densely packed, group of cholinergic cells receives projections from the ipsilateral SGS and in turn projects bilaterally to SGS in 
mammals (Edwards et al., 1979; Roldan et al., 1983; Mufson et al., 1986; Taylor et al., 1986; Hall et al., 1989; Baizer et al., 1991; Jiang et al., 1996). Similar pathways are present in nonmammalian vertebrates ranging from fish to birds, and, in the pigeon, excitation of the apparent parabigeminal nucleus homolog, nucleus isthmi parvocellularis, increases the inhibition of tectal cells (King and Schmidt, 1991a,b; Wang et al., 2000).

One clue to the function of this cholinergic pathway is the finding that the observed $\mathrm{ACh}$-induced reductions in excitability of SGS projection cells are mediated by $\mathrm{GABA}_{\mathrm{B}}$ receptors. Compared with $\mathrm{GABA}_{\mathrm{A}}$ receptors, $\mathrm{GABA}_{\mathrm{B}}$ receptors typically give rise to longer-lasting outward currents that are slower to reach their peak and are accompanied by small conductance changes (Bormann, 1988). These properties, together with the indirect route from SGS to the parabigeminal nucleus back to SGS, suggest that this cholinergic pathway does not contribute to the ongoing temporal and spatial modulation of visual inputs to SGS. One alternative is that the $\mathrm{ACh}$-mediated $\mathrm{GABA}_{\mathrm{B}}$ currents deinactivate low-threshold channels by hyperpolarizing the SGS projection cells (Crunelli and Leresche, 1991). After depolarization by subsequent visual inputs to SGS, the projection cells may generate $\mathrm{Ca}$ spikes with superimposed bursts of $\mathrm{Na}$ spikes (Scharfman et al., 1990). Such bursts have been observed in SGS (Lo and Mize, 2000) and may serve to amplify the responses of SGS projection cells to salient stimuli that appear in the visual field subsequent to an orienting movement. This amplified signal may then be transmitted by the projection cells to other structures, including the visual cortex via the thalamus and the premotor cells of the deeper layers, which in turn may command a subsequent saccade to a salient stimulus. A similar role for the bursts generated by low-threshold $\mathrm{Ca}$ spikes has been proposed for sensory relay cells in the thalamus, and cholinergic pathways from the brainstem also modulate this mechanism (McCormick and Pape, 1988; Guido et al., 1995; Sherman, 1996; Reinagel et al., 1999). However, additional experiments will be necessary to establish that an analogous mechanism functions in SGS to amplify novel visual signals that appear after a shift in the direction of gaze.

\section{REFERENCES}

Aubert I, Cecyre D, Gauthier S, Quirion R (1992) Characterization and autoradiographic distribution of [3H]AF-DX 384 binding to putative muscarinic M2 receptors in the rat brain. Eur J Pharmacol 217:173-184.

Baizer JS, Whitney JF, Bender DB (1991) Bilateral projections from the parabigeminal nucleus to the superior colliculus in monkey. Exp Brain Res 86:467-470.

Basbaum AI, Menetrey D (1987) Wheat germ agglutinin-apoHRP gold: a new retrograde tracer for light- and electron-microscopic single- and double-label studies. J Comp Neurol 261:306-318.

Benevento LA, Fallon JH (1975) The ascending projections of the superior colliculus in the rhesus monkey (Macaca mulatta). J Comp Neurol 160:339-361.

Binns KE (1999) The synaptic pharmacology underlying sensory processing in the superior colliculus. Prog Neurobiol 59:129-159.

Binns KE, Salt TE (1997) Different roles for GABA $A$ and $\mathrm{GABA}_{\mathrm{B}}$ receptors in visual processing in the rat superior colliculus. J Physiol (Lond) 504:629-639.

Binns KE, Salt TE (2000) The functional influence of nicotinic cholinergic receptors on the visual responses of neurones in the superficial superior colliculus. Vis Neurosci 17:283-289.

Bormann J (1988) Electrophysiology of $\mathrm{GABA}_{\mathrm{A}}$ and $\mathrm{GABA}_{\mathrm{B}}$ receptor subtypes. Trends Neurosci 11:112-116.

Clarke PB, Schwartz RD, Paul SM, Pert CB, Pert A (1985) Nicotinic binding in rat brain: autoradiographic comparison of $\left[{ }^{3} \mathrm{H}\right]$ acetylcholine, [ $\left.{ }^{3} \mathrm{H}\right]$ nicotine, and $\left[{ }^{125} \mathrm{I}\right] \alpha$-bungarotoxin. J Neurosci 5:1307-1315.

Crunelli V, Leresche N (1991) A role for $\mathrm{GABA}_{\mathrm{B}}$ receptors in excitation and inhibition of thalamocortical cells. Trends Neurosci 14:16-21.

Edwards FA, Konnerth A, Sakmann B, Takahashi T (1989) A thin slice preparation for patch clamp recordings from neurones of the mammalian central nervous system. Pflügers Arch 414:600-612.
Edwards SB, Ginsburgh CL, Henkel CK, Stein BE (1979) Sources of subcortical projections to the superior colliculus in the cat. J Comp Neurol 184:309-329.

Graybiel AM (1978) A satellite system of the superior colliculus: the parabigeminal nucleus and its projections to the superficial collicular layers. Brain Res 145:365-374.

Guido W, Lu SM, Vaughan JW, Godwin DW, Sherman SM (1995) Receiver operating characteristic (ROC) analysis of neurons in the cat's lateral geniculate nucleus during tonic and burst response mode. Vis Neurosci 12:723-741.

Hall WC, Lee P (1993) Interlaminar connections of the superior colliculus in the tree shrew. I. The superficial gray layer. J Comp Neurol 332:213-223.

Hall WC, Lee P (1997) Interlaminar connections of the superior colliculus in the tree shrew. III. The optic layer. Vis Neurosci 14:647-661.

Hall WC, Fitzpatrick D, Klatt LL, Raczkowski D (1989) Cholinergic innervation of the superior colliculus in the cat. J Comp Neurol 287:495-514.

Harting JK (1977) Descending pathways from the superior colliculus: an autoradiographic analysis in the rhesus monkey (Macaca mulatta). J Comp Neurol 173:583-612.

Harting JK, Casagrande VA, Weber JT (1978) The projection of the primate superior colliculus upon the dorsal lateral geniculate nucleus: autoradiographic demonstration of interlaminar distribution of tectogeniculate axons. Brain Res 150:593-599.

Henderson Z (1989) The cholinergic input to the superficial layers of the superior colliculus: an ultrastructural immunocytochemical study in the ferret. Brain Res 476:149-153.

Holstege G, Collewijn H (1982) The efferent connections of the nucleus of the optic tract and the superior colliculus in the rabbit. J Comp Neurol 209:139-175

Hutsler JJ, Chalupa LM (1991) Substance P immunoreactivity identifies a projection from the cat's superior colliculus to the principal tectorecipient zone of the lateral posterior nucleus. J Comp Neurol 312:379-390.

Jeon CJ, Spencer RF, Mize RR (1993) Organization and synaptic connections of cholinergic fibers in the cat superior colliculus. J Comp Neurol 333:360-374.

Jiang ZD, King AJ, Moore DR (1996) Topographic organization of projection from the parabigeminal nucleus to the superior colliculus in the ferret revealed with fluorescent latex microspheres. Brain Res 743:217-232.

Katz LC, Burkhalter A, Dreyer WJ (1984) Fluorescent latex microspheres as a retrograde neuronal marker for in vivo and in vitro studies of visual cortex. Nature 310:498-500.

King WM, Schmidt JT (1991a) A cholinergic circuit intrinsic to optic tectum modulates retinotectal transmission via presynaptic nicotinic receptors. Ann NY Acad Sci 627:363-367.

King WM, Schmidt JT (1991b) The long latency component of retinotectal transmission: enhancement by stimulation of nucleus isthmi or tectobulbar tract and block by nicotinic cholinergic antagonists. Neuroscience 40:701-712.

Künzle H (1997) Connections of the superior colliculus with the tegmentum and the cerebellum in the hedgehog tenrec. Neurosci Res 28:127-145.

Lee P, Hall WC (1995) Interlaminar connections of the superior colliculus in the tree shrew. II. Projections from the superficial gray to the optic layer. Vis Neurosci 12:573-588.

Lee PH, Helms MC, Augustine GJ, Hall WC (1997) Role of intrinsic circuitry in collicular sensorimotor integration. Proc Natl Acad Sci USA 94:13299-13304.

Levey AI, Edmunds SM, Heilman CJ, Desmond TJ, Frey KA (1994) Localization of muscarinic $\mathrm{m} 3$ receptor protein and $\mathrm{M} 3$ receptor binding in rat brain. Neuroscience 63:207-221.

Lo FS, Mize RR (2000) Synaptic regulation of L-type $\mathrm{Ca}^{2+}$ channel activity and long-term depression during refinement of the retinocollicular pathway in developing rodent superior colliculus. J Neurosci 20:RC58(1-6).

McCormick DA, Pape HC (1988) Acetylcholine inhibits identified interneurons in the cat lateral geniculate nucleus. Nature 334:246-248.

McHaffie JG, Beninato M, Stein BE, Spencer RF (1991) Postnatal development of acetylcholinesterase in, and cholinergic projections to, the cat superior colliculus. J Comp Neurol 313:113-131.

Mendez F, Penner R (1998) Near-visible ultraviolet light induces a novel ubiquitous calcium-permeable cation current in mammalian cell lines. J Physiol (Lond) 507:365-377.

Menetrey D (1985) Retrograde tracing of neural pathways with a protein-gold complex. I. Light microscopic detection after silver intensification. Histochemistry 83:391-395.

Mize RR (1992) The organization of GABAergic neurons in the mammalian superior colliculus. Prog Brain Res 90:219-248.

Mooney RD, Nikoletseas MM, Ruiz SA, Rhoades RW (1988) Receptive-field properties and morphological characteristics of the superior collicular neurons that project to the lateral posterior and 
dorsal lateral geniculate nuclei in the hamster. J Neurophysiol 59:1333-1351.

Mufson EJ, Martin TL, Mash DC, Wainer BH, Mesulam MM (1986) Cholinergic projections from the parabigeminal nucleus $(\mathrm{Ch} 8)$ to the superior colliculus in the mouse: a combined analysis of horseradish peroxidase transport and choline acetyltransferase immunohistochemistry. Brain Res 370:144-148.

Perry DC, Kellar KJ (1995) [ ${ }^{3} \mathrm{H}$ epibatidine labels nicotinic receptors in rat brain: an autoradiographic study. J Pharmacol Exp Ther 275:1030-1034.

Prusky GT, Cynader MS (1988) [3H]nicotine binding sites are associated with mammalian optic nerve terminals. Vis Neurosci 1:245-248.

Redgrave P, Mitchell IJ, Dean P (1987) Descending projections from the superior colliculus in rat: a study using orthograde transport of wheatgerm-agglutinin conjugated horseradish peroxidase. Exp Brain Res 68:147-167.

Reese BE (1984) The projection from the superior colliculus to the dorsal lateral geniculate nucleus in the rat. Brain Res 305:162-168.

Reinagel P, Godwin D, Sherman SM, Koch C (1999) Encoding of visual information by LGN bursts. J Neurophysiol 81:2558-2569.

Robson JA, Hall WC (1976) Projections from the superior colliculus to the dorsal lateral geniculate nucleus of the grey squirrel. Brain Res 113:379-385

Roldan M, Reinoso-Suarez F, Tortelly A (1983) Parabigeminal projections to the superior colliculus in the cat. Brain Res 280:1-13.

Scharfman HE, Lu SM, Guido W, Adams PR, Sherman SM (1990) $N$-methyl-D-aspartate receptors contribute to excitatory postsynaptic potentials of cat lateral geniculate neurons recorded in thalamic slices. Proc Natl Acad Sci USA 87:4548-4552.

Schmidt M, Boller M, Özen G, Hall WC (2001) Disinhibition in rat superior colliculus mediated by $\mathrm{GABA}_{\mathrm{C}}$ receptors. J Neurosci 21:691-699.
Sefton AJ, Martin PR (1984) Relation of the parabigeminal nucleus to the superior colliculus and dorsal lateral geniculate nucleus in the hooded rat. Exp Brain Res 56:144-148.

Sherk H (1979) Connections and visual-field mapping in cat's tectoparabigeminal circuit. J Neurophysiol 42:1656-1668.

Sherman SM (1996) Dual response modes in lateral geniculate neurons: mechanisms and functions. Visual Neurosci 13:205-213.

Tan MM, Harvey AR (1989) The cholinergic innervation of normal and transplanted superior colliculus in the rat: an immunohistochemical study. Neuroscience 32:511-520.

Taylor AM, Jeffery G, Lieberman AR (1986) Subcortical afferent and efferent connections of the superior colliculus in the rat and comparisons between albino and pigmented strains. Exp Brain Res 62:131-142.

Torrealba F, Partlow GD, Guillery RW (1981) Organization of the projection from the superior colliculus to the dorsal lateral geniculate nucleus of the cat. Neuroscience 6:1341-1360.

Wang Y, Xiao J, Wang SR (2000) Excitatory and inhibitory receptive fields of tectal cells are differentially modified by magnocellular and parvocellular divisions of the pigeon nucleus isthmi. J Comp Physiol [A] 186:505-511.

Watanabe K, Kawana E (1979) Efferent projections of the parabigeminal nucleus in rats: a horseradish peroxidase (HRP) study. Brain Res 168:1-11.

Whiteaker P, McIntosh JM, Luo S, Collins AC, Marks MJ (2000) 125Ialpha-conotoxin MII identifies a novel nicotinic acetylcholine receptor population in mouse brain. Mol Pharmacol 57:913-925.

Winer JA, Saint Marie RL, Larue DT, Oliver DL (1996) GABAergic feedforward projections from the inferior colliculus to the medial geniculate body. Proc Natl Acad Sci USA 93:8005-8010.

Zubieta JK, Frey KA (1993) Autoradiographic mapping of M3 muscarinic receptors in the rat brain. J Pharmacol Exp Ther 264:415-422. 